\section{Perception of the value of generic drugs in São Paulo, Brazil}

\author{
Percepção de valor de medicamentos genéricos \\ em São Paulo, Brasil
}

\author{
Percepción del valor de las medicinas genéricas en \\ São Paulo, Brasil
}

\begin{abstract}
The objective of this study was to assess the perceptions of opinion-leaders, patients and their accompanying family members or carers about generic drugs. Three groups of participants were surveyed: (i) 50 customers while they were visiting commercial pharmacies located in São Paulo city, Brazil, (ii) 25 patients and 25 companions while they were waiting at the university outpatient clinic, and (iii) 50 healthcare opinion-leaders from government, hospitals, health plans, academia, and pharmaceutical companies. The questions explored socio-demographic characteristics and perceptions regarding value attributes of generic drugs compared to brand name drugs. Respondents had an average age of 52 years and 53\% were women. Respondents believed generic drugs to be cheaper than brand name drugs (97\%), and 31\% thought generic drugs to be less effective than brand name drugs. Also, generic drugs were perceived by 54\% of respondents to be as safe as brand name drugs and 74\% would prefer brand name drugs if there was no price difference. In conclusion, multiple factors may contribute to the decision to buy generic drugs; among these, perceived effectiveness, safety and price appear to be the most important factors.
\end{abstract}

Generic Drugs; Reference Drugs; Drug Utilization
Elene Paltrinieri Nardi 1

Marcos Bosi Ferraz 1

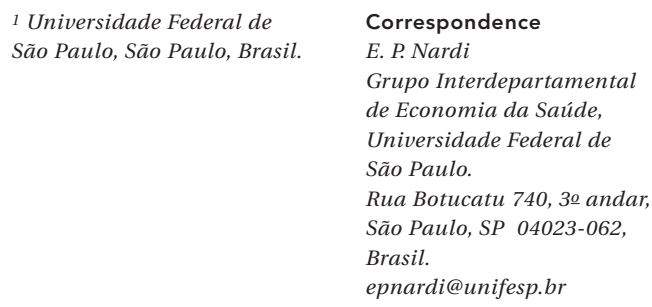

1 Universidade Federal de São Paulo, São Paulo, Brasil.

Correspondence

E. P. Nardi

Grupo Interdepartamental de Economia da Saúde, Universidade Federal de São Paulo.

Rua Botucatu 740, 3o andar, São Paulo, SP 04023-062,

Brasil.

epnardi@unifesp.br 


\section{Introduction}

According to the report World Health Statistics 2013 1, health expenditures in Brazil increased from $7.2 \%$ to $9 \%$ of gross domestic product (GDP) in 10 years, approaching the world average of $9.2 \%$. Of the total health expenditure in Brazil, $53 \%$ is private, much higher than the $41.1 \%$ global average 1 . Drugs caused the majority of expenditure on healthcare by Brazilian families (Brazilian Household Budget Survey 2008-2009 - POF). Generic drugs may potentially help to reduce private healthcare expenditure in Brazil 2.

Generic drugs were approved in Brazil in 1999 under Law n. 9.787/1999 3, and may be marketed if equivalent to the reference product and produced to the Brazilian National Agency for Sanitary Surveillance (ANVISA) quality standards 4,5 . Generic drugs prices must be $35 \%$ below their respective reference prices ${ }^{6}$. In São Paulo, Brazil, the mean price of generic drugs was $56.63 \%$ lower than that of the reference drugs in August 20137.

The interchange between generic drugs and reference drugs can occur at the time of purchase and upon patients' request, except where the prescriber requested "not to substitute" ${ }^{4}$. In the public healthcare system, physicians must prescribe drugs by their Brazilian Common Denomination (Denominação Comum Brasileira - DCB) or, if absent, by the International Nonproprietary Name (INN) 8. However, despite the legislation that supports the prescription of generic drugs, generic drugs still have a small market share, representing $27.3 \%$ of all drug units sold in Brazil in January 20149.

A potential reason for the low penetration of generic drugs into the Brazilian market is a potential negative perception of the value of generic drugs. A study performed by Quintal \& Mendes 10 with patients and pharmacists in Portugal indicated that a low rate of generic prescriptions, lack of confidence in generic drugs and poor knowledge by patients were the main reasons for low generic drugs utilization.

Generics were often perceived by a certain percentage of the population as being less effective, less safe and of inferior quality compared to the reference drugs 11,12,13. Less than half of the 441 consumers from pharmacies in Auckland, New Zealand, considered generic drugs to be as safe, effective, and equivalent in quality, as their respective brand name drugs 14 . Shank et al. 15 found that $29.9 \%$ of 1,047 insured beneficiaries surveyed in the United States believed that brand name drugs were more effective than generic drugs. In Southern Brazil, $33.8 \%$ of 374 interviewed adults in 2011 considered generic drugs to be products of lesser quality or did not know they existed 16.

Even physicians in Finland reported concerns regarding generic drugs 17 . One year after the introduction of generic drugs substitution, it was observed that although $86 \%$ of the 49 physicians interviewed considered the substitution with generic drugs to be beneficial, more than half believed that genric drugs were not necessarily as effective as brand name drugs ${ }^{18}$. Another study 19 assessed psychological factors associated with the prescription of generic drugs by general practitioners in Spain, and observed that the biggest deterrent was the perceived opposition by patients against generic drugs and the time spent on educating patients about generic drugs 19 .

The knowledge about the value attributes perceived by the population regarding generic drugs versus brand name drugs is still limited in Brazil. The aim of this study was to better understand the attributes leading to the value perceptions of generic drugs or brand name drugs by opinion-leaders, patients and their companions.

\section{Methods}

A cross-sectional survey was applied between March and August 2013. The sample consisted of three groups of respondents: (i) the first group was composed of 50 pharmacy customers, which were consecutively selected and interviewed while visiting seven commercial pharmacies located in different regions of the city of São Paulo. Three of the largest pharmacy chains of São Paulo were invited to participate in this study. The first one who agreed to participate was chosen for the interviews. The pharmacies were selected according to the availability of each and included one in each region: north, south, east, west and central zone of the city. The interviews were held for two days in each pharmacy and, if 10 respondents were not reached, another pharmacy of the same chain was selected in the same region of the city until the number of 50 respondents was attained; (ii) the second group was composed of 25 patients and 25 companions. The participants were consecutively selected and interviewed while waiting for their regular outpatient visits at the university outpatient clinic. The interviews were consecutively conducted in different days and hours until the sample of 50 subjects was reached; and (iii) the third group was composed of 50 opinion-leaders from government, hospitals, health-plans, academia, and pharmaceutical companies. To this end, a database with 124 opinion-leaders was created using personal contacts of the research team group. All respondents 
were invited to take part in this study by an email message and interviews were scheduled with those who accepted the invitation. Reminder emails were sent after 24 days.

Inclusion criteria for the interviewees at the pharmacies and the outpatient clinic were age $>$ 40 and literacy. Inclusion criteria for the opinionleaders' group were age $>30$, over 5 years of professional activity in the healthcare area and being in a leadership position in the government/ public healthcare system (10), health-plans (10), public and private hospitals (10), academia (10) and the pharmaceutical industry (10). All participants signed a consent form before starting the interview.

A standardized text summarizing key definitions in the current Brazilian drug market and the main objectives of the study were presented to all interviewees. Three general questions were asked to evaluate their knowledge about generic drugs. 15 questions addressed the respondents' views and perceptions regarding value attributes of generic drugs in comparison to brand name drugs. The questionnaire explored socioeconomic, demographic and educational data and applied the SF-6D Brazil (Short Form 6 Dimension) questionnaire to determine the quality of life of respondents. Descriptive statistics were used to examine demographics and socioeconomic characteristics of the samples.

There was no mention of any pharmaceutical company, as well as specific generic drugs or brand name drugs, during the interviews.

All interviews were conducted by a registered pharmacist (E.P.N.). The study protocol was reviewed and approved by the Ethics Research Committee of São Paulo Federal University (UNIFESP/EPM).

\section{Results}

A total of 148 people were interviewed. These included 50 pharmacy customers, 50 people in the clinics of São Paulo Hospital (UNIFESP/EPM - 25 patients and 25 companions), and 48 opinionleaders from public healthcare (8), health insurance companies (10), public or private hospital service providers (10), academic, educational and research institutions (10), and pharmaceutical companies (10).

In the pharmacies, 203 people refused to participate (102 men and 101 women; response rate $19.8 \%)$. At the hospital, 27 people refused or discontinued participation during the interview due to being called to their appointment (response rate $64.9 \%$ ). From all invited opinion-leaders, 17 people did not attend, 12 refused to participate, and 47 people did not answer the invitation (total response rate $38.7 \%$ ).

The demographics and socioeconomic characteristics of the 148 respondents are described in Table 1 . Of the respondents, $53 \%$ were women, the average age was 52 years, $59 \%$ had health insurance, $38 \%$ used the public health system all or most of the time, and $60 \%$ had over 8 years of formal education. The average quality of life measured by the SF-6D questionnaire was 0.77 . Considerable differences in respondents' socioeconomic characteristics were observed, mainly regarding their income and education.

Regarding overall understanding of generic drugs, users from pharmacies and hospitals were more informed about the price difference between generic drug and brand name drug than opinion-leaders, while opinion-leaders were more aware of the regulatory requirements for marketing generic drugs: only $44 \%$ of pharmacy customers and $28 \%$ of hospital customers knew that there are different requirements for regulatory approval of brand name drugs or generic drugs (Table 2).

Table 3 and Table 4 show value attributes as recognized by each of the groups. The majority of respondents believed that generic drug and brand name drug were equally effective (66\%) and that they cause an equal number of side effects (67\%). Comparing with the two other groups, more opinion-leaders believed generic drug and brand name drug to be equally effective (73\%) and that genric drugs cause as many side effects as brand name drugs (90\%) (Table 3).

Overall, 65\% $(n=97)$ of respondents agreed with the statement that generic drug and brand name drug are similar in quality, while between $22 \%$ (in hospital) and 29\% (opinion-leaders) of respondents said they believed generic drug were of an overall poorer quality compared with BD (Table 3).

Regarding the statement "generic drugs are as suitable or appropriate as brand name drugs for mild, trivial or less serious diseases" $57 \%$ of respondents $(n=84)$ agreed with this statement, while $23 \%(n=34)$ considered generic drug to be more suitable for these conditions.

Of all respondents, $54 \%$ agreed that generic drug and brand name drug have the same safety profile. Nevertheless, $48 \%$ of the pharmacy, $44 \%$ of the hospital, and $71 \%$ of the opinion-leader group stated that brand name drug was safer than generic drug.

A slightly higher proportion of participants (46\%) agreed to "getting confused in the pharmacy when offered more drugs with the same name or active ingredient". This was more pronounced in the hospital $(74 \%)$ than in the phar- 
Demographic and economic characteristics of the studied sample.

\begin{tabular}{|c|c|c|c|c|}
\hline & $\begin{array}{l}\text { All groups } \\
\text { n (\%) }\end{array}$ & $\begin{array}{c}\text { Patients/Companions } \\
\text { pharmacy } \\
n(\%)\end{array}$ & $\begin{array}{l}\text { Patients/Companions } \\
\text { public hospital } \\
\text { n (\%) }\end{array}$ & $\begin{array}{c}\text { Opinion-leaders } \\
\text { n (\%) }\end{array}$ \\
\hline Total & $148(100)$ & $50(100)$ & $50(100)$ & $48(100)$ \\
\hline Age: mean (SD) & $52(10)$ & $54(8)$ & $54(9)$ & $46(10)$ \\
\hline \multicolumn{5}{|l|}{ Gender } \\
\hline Male & $70(47)$ & $20(40)$ & $23(46)$ & $27(56)$ \\
\hline Female & $78(53)$ & $30(60)$ & $27(54)$ & $21(44)$ \\
\hline \multicolumn{5}{|l|}{ Family income (minimum wages) } \\
\hline Less than 2 (USD 627.78) & $33(22)$ & $12(24)$ & $21(42)$ & $0(0)$ \\
\hline 3 to 5 & $26(18)$ & $8(16)$ & $18(36)$ & $0(0)$ \\
\hline 6 to 15 & $28(19)$ & $16(32)$ & $4(8)$ & $8(17)$ \\
\hline More than 16 & $53(36)$ & $9(18)$ & $4(8)$ & $40(83)$ \\
\hline Did not answer & $8(5)$ & $5(10)$ & $3(6)$ & $0(0)$ \\
\hline \multicolumn{5}{|l|}{ Education (years) * } \\
\hline Up to 4 & $25(17)$ & $4(8)$ & $21(42)$ & $0(0)$ \\
\hline From 5-7 & $34(23)$ & $14(28)$ & $20(40)$ & $0(0)$ \\
\hline More than 8 & $89(60)$ & $32(64)$ & $9(18)$ & $48(100)$ \\
\hline \multicolumn{5}{|l|}{ Private health plan } \\
\hline Yes & $88(59)$ & $32(64)$ & $13(26)$ & $43(90)$ \\
\hline No & $60(41)$ & $18(36)$ & $37(74)$ & $5(10)$ \\
\hline \multicolumn{5}{|l|}{ Use of public healthcare system } \\
\hline Always or most of the time & 57 (39) & $12(24)$ & $42(84)$ & $3(6)$ \\
\hline Never or rarely & $91(61)$ & $35(70)$ & $8(16)$ & $44(92)$ \\
\hline SF-6D mean (SD) & $0.77(0.13)$ & $0.76(0.12)$ & $0.72(0.15)$ & $0.82(0.09)$ \\
\hline
\end{tabular}

SD: standard deviation.

* The years of education of the population studied were counted from the 6th grade onward, as discussed by Law n. 11,274 27, which extends the elementary school to nine years in duration in Brazil.

macy $(\mathrm{n}=42 \%)$ or among opinion-leaders with $21 \%(\mathrm{n}=10)$ agreement (Table 4$)$.

When asked about their perception of the statement "If there was not a price difference (generics are cheaper), I would always prefer taking a brand name drug", the majority of participants (74\%) agreed with it.

More than half of respondents (59\%) disagreed with the statement that "doctors prefer to prescribe generic drug". There was a higher disagreement $(79 \%, \mathrm{n}=38$ ) observed with opinionleaders and with pharmacy respondents $(62 \%$, $\mathrm{n}=31)$ than in the hospital $(36 \%, \mathrm{n}=18)$.

Of all respondents, $56 \%(n=83)$ indicated that they would not accept advice from the pharmacist or salesperson concerning generic drugs, with the highest rejection reported by the opinion-leaders group (65\%). Only in the hospital group more respondents indicated that they would listen to such advice (52\%).
Finally, more than half of all respondents (54\%) disagreed to always buying generic drugs if they could afford to buy brand name drugs. The disagreement was strongest among the opinionleaders $(60 \%)$; followed by the hospital group (52\%) and the pharmacy group (50\%) (Table 4).

\section{Discussion}

The present study is the first comparison of the perceptions of opinion-leaders, patients and companions regarding generic drug or brand name drug in Brazil.

The preferences of consumers are important for healthcare choices and in order to improve healthcare efficiency. Moreover, the opinion of opinion-leaders can be an important indicator for the consistency of the generic policies. Their opinions translate in both regulatory and 
Overall understanding about generic drugs, according to the research groups.

\begin{tabular}{|c|c|c|c|c|}
\hline & \multirow[t]{2}{*}{ All } & \multicolumn{3}{|c|}{ Groups } \\
\hline & & $\begin{array}{c}\text { Patients/ Companions } \\
\text { pharmacy } \\
\text { n (\%) }\end{array}$ & $\begin{array}{l}\text { Patients/Companions } \\
\text { public hospital } \\
\text { n (\%) }\end{array}$ & $\begin{array}{l}\text { Opinion-leaders } \\
\text { n (\%) }\end{array}$ \\
\hline Knew of the existence of generic drugs & $148(100)$ & $50(100)$ & $50(100)$ & $48(100)$ \\
\hline $\begin{array}{l}\text { Generic drugs do not need all the safety and } \\
\text { effectiveness studies for regulatory approval and } \\
\text { market authorization as brand name drugs }\end{array}$ & $78(53)$ & $22(44)$ & $14(28)$ & $42(87)$ \\
\hline $\begin{array}{l}\text { Generic drugs are required by law to be priced at } \\
\text { least } 35 \% \text { cheaper than the corresponding brand } \\
\text { name drug }\end{array}$ & $93(63)$ & $32(64)$ & $38(76)$ & $23(48)$ \\
\hline
\end{tabular}

supervisory actions required for the production of safe products with high quality.

In terms of the general knowledge about generic drugs, consumers were more aware of the price difference between generic drug and brand name drug than opinionleaders, whilst opinion-leaders, working in health care, were better informed about the regulatory requirements for drug marketing. It should be noted however, that the opinionleader group was a broad stakeholder mix involving government, hospitals, healthplans, academia, and pharmaceutical companies; and differences may exist in attitudes depending on their professional perspectives.

The perception of generic drugs was generally more positive than negative when asked for specific value attributes such as effectiveness, safety or price. Nevertheless, the overall value appeared to be perceived higher for brand name drug as shown by the preference for brand name drugs in the case of equal price. In addition, there is a constant proportion of respondents who perceive generic drug as being less effective than brand name drugs $(31 \%)$ as well as of a lower quality (26\%).

The perception of reduced effectiveness of generic drugs was underlined by some respondents' verbal descriptions during the interviews, i.e. generic drugs were "weaker products". One pharmacy interviewee mentioned: "I think generic drugs are very weak, I do not take generic drugs"; and another said: "sometimes I take a generic drug and feel no effect". Sewell's qualitative study conducted in two counties in the rural Alabama Black Belt with 30 community members also noted perceptions of some respondents that generic drugs are less potent 20 .
Of opinion-leaders, $29 \%$ were concerned with quality deviations $(26 \%$ of pharmacy respondents and $22 \%$ of hospital respondents shared the concern). This degree of concern is slightly lower than that observed by Shrank et al. 17 with almost half of the 506 physicians surveyed having concerns about the quality of generic drugs.

One opinion-leader stated that multinational companies produce higher quality drugs due to their global standards. Most brand name drugs sold in Brazil today are from multinational companies, while $90 \%$ of generic drug registrations in the ANVISA in November 2013 were products from Brazilian companies 21.

Although the majority of respondents believed that brand name drug and generic drug are equally safe $(54 \%), 40 \%$ of participants agreed in another question that brand name drug were safer than generic drug. Even $27 \%$ of the opinion-leaders thought that brand name drugs were safer than generic drugs, which raises the concern that opinion leaders do not trust in the current regulation and inspection processes involving generic drug in the country. One opinion-leader underlined his lack of confidence about generic drug safety saying that "generic drug have no clinical research justifying the safety of their use".

Likewise, in Germany, a considerable proportion of patients (37\%) expressed general skepticism towards generic drugs because of their lower price 12 . Less than half of the 441 consumers from pharmacies in Auckland, considered generic drug to be as safe, effective and equivalent in quality as the respective brand name drug 14 . Interviews with 1,000 individuals (15-74 years old) in Switzerland found that $10 \%$ thought that 
Table 3

Perception of value attributes of generic drugs (effectiveness, side effects, quality, use, time, safety, price) by the surveyed groups.

\begin{tabular}{|c|c|c|c|c|}
\hline \multirow[t]{2}{*}{ Attribute } & \multirow[t]{2}{*}{ All } & \multicolumn{3}{|c|}{ Groups } \\
\hline & & $\begin{array}{c}\text { Patients/ } \\
\text { Companions } \\
\text { pharmacy } \\
n(\%)\end{array}$ & $\begin{array}{c}\text { Patients/ } \\
\text { Companions } \\
\text { public hospital } \\
\text { n (\%) }\end{array}$ & Opinion-leaders \\
\hline \multicolumn{5}{|l|}{ Effectiveness } \\
\hline 1. Generic drugs are less effective than brand name drugs & $46(31)$ & $17(34)$ & $19(38)$ & $10(21)$ \\
\hline 2. Generic drugs are as effective as brand name drugs & $98(66)$ & $32(64)$ & $31(62)$ & $35(73)$ \\
\hline 3. Generic drugs are more effective than brand name drugs & $0(0)$ & $0(0)$ & $0(0)$ & $0(0)$ \\
\hline 4. I don't know/Did not answer & $4(3)$ & $1(2)$ & $0(0)$ & $3(6)$ \\
\hline \multicolumn{5}{|l|}{ Side effects } \\
\hline $\begin{array}{l}\text { 1. Generic drugs cause fewer side effects than brand name } \\
\text { drugs }\end{array}$ & $10(7)$ & $0(0)$ & $9(18)$ & $1(2)$ \\
\hline $\begin{array}{l}\text { 2. Generic drugs cause as many side effects as brand name } \\
\text { drugs }\end{array}$ & $99(67)$ & $33(66)$ & $23(46)$ & $43(90)$ \\
\hline $\begin{array}{l}\text { 3. Generic drugscause more side effects than brand name } \\
\text { drugs }\end{array}$ & $6(4)$ & $3(6)$ & $3(6)$ & $0(0)$ \\
\hline 4. I don't know/Did not answer & $33(22)$ & $14(28)$ & $15(30)$ & $4(8)$ \\
\hline \multicolumn{5}{|l|}{ Quality } \\
\hline $\begin{array}{l}\text { 1. Generic drugs have an overall worse quality than brand } \\
\text { name drugs }\end{array}$ & $38(26)$ & $13(26)$ & $11(22)$ & $14(29)$ \\
\hline $\begin{array}{l}\text { 2. generic drugs have an overall similar quality as brand } \\
\text { name drugs }\end{array}$ & $97(65)$ & $32(64)$ & $33(66)$ & $32(67)$ \\
\hline $\begin{array}{l}\text { 3. Generic drugs have an overall better quality than brand } \\
\text { name drugs }\end{array}$ & $3(2)$ & $0(0)$ & $3(6)$ & $0(0)$ \\
\hline 4. I don't know/Did not answer & $10(7)$ & $5(10)$ & $3(6)$ & $2(4)$ \\
\hline \multicolumn{5}{|l|}{ Use } \\
\hline $\begin{array}{l}\text { 1. Generic drugs are more suitable or appropriate than } \\
\text { brand name drugs for mild, trivial or less serious diseases }\end{array}$ & $34(23)$ & $11(22)$ & $15(30)$ & $8(17)$ \\
\hline $\begin{array}{l}\text { 2. Generic drugs are as suitable or appropriate as brand } \\
\text { name drugs for mild, trivial or less serious diseases }\end{array}$ & $84(57)$ & $30(60)$ & $20(40)$ & $34(71)$ \\
\hline $\begin{array}{l}\text { 3. Generic drugs are less suitable or appropriate than brand } \\
\text { name drugs for mild, trivial or less serious diseases }\end{array}$ & $27(18)$ & $8(16)$ & $14(28)$ & $5(10)$ \\
\hline 4. I don't know/Did not answer & $3(2)$ & $1(2)$ & $1(2)$ & $1(2)$ \\
\hline \multicolumn{5}{|l|}{ Time } \\
\hline $\begin{array}{l}\text { 1. Generic drugs take less time to make effect when } \\
\text { compared to brand name drugs }\end{array}$ & $4(3)$ & $3(6)$ & $1(2)$ & $0(0)$ \\
\hline $\begin{array}{l}\text { 2. Generic drugs take the same time to make effect when } \\
\text { compared to brand name drugs }\end{array}$ & $96(65)$ & $30(60)$ & $30(60)$ & $36(75)$ \\
\hline $\begin{array}{l}\text { 3. Generic drugs take more time to make effect when } \\
\text { compared to brand name drugs }\end{array}$ & $32(22)$ & $11(22)$ & $14(28)$ & $7(15)$ \\
\hline 4. I don't know/Did not answer & $16(11)$ & $6(12)$ & $5(10)$ & $5(10)$ \\
\hline \multicolumn{5}{|l|}{ Safety } \\
\hline 1. Brand name drugs are less safe than generic drugs & $3(2)$ & $1(2)$ & $2(4)$ & $0(0)$ \\
\hline 2. Brand name drugs are as safe as generic drugs & $80(54)$ & $22(44)$ & $24(48)$ & $34(71)$ \\
\hline 3. Brand name drugs are safer than generic drugs & $59(40)$ & $24(48)$ & $22(44)$ & $13(27)$ \\
\hline 4. I don't know & $6(4)$ & $3(6)$ & $2(4)$ & $1(2)$ \\
\hline
\end{tabular}

(continues) 
Table 3 (continued)

\begin{tabular}{|c|c|c|c|c|}
\hline \multirow[t]{5}{*}{ Attribute } & \multirow[t]{4}{*}{ All } & \multicolumn{3}{|c|}{ Groups } \\
\hline & & Patients/ & Patients/ & Opinion-leaders \\
\hline & & Companions & Companions & \\
\hline & & pharmacy & public hospital & \\
\hline & n (\%) & n (\%) & n (\%) & n (\%) \\
\hline \multicolumn{5}{|l|}{ Price } \\
\hline 1. Brand name drugs are more expensive than generic drugs & $144(97)$ & $49(98)$ & $50(100)$ & $45(94)$ \\
\hline 2. Brand name drugs are cheaper than generic drugs & $0(0)$ & $0(0)$ & $0(0)$ & $0(0)$ \\
\hline 3. Brand name drugs have the same price of generic drugs & $0(0)$ & $0(0)$ & $0(0)$ & $0(0)$ \\
\hline 4. I don't know/Did not answer & $4(3)$ & $1(2)$ & $0(0)$ & $3(6)$ \\
\hline
\end{tabular}

generic drugs were not effective or safe; $12 \%$ refused to use them 22 . Another study by Hakonsen et al. 23 with 174 outpatients in Oslo and Bergen in Norway revealed that $29 \%$ of patients were anxious when they started to use a substitute generic drug; $8 \%$ felt that the drug effect changed, and $15 \%$ reported having new or more side effects from the substitute. In pharmacies in Oslo, some of 22 patients who had already made use of antihypertensive generic and brand name drugs mentioned experiencing more side effects and weaker effects upon drug substitution 24. In two studies conducted in Southern Brazil (2002 and 2011), it was observed that $70 \%$ of 3,182 respondents and $64.3 \%$ of 374 respondents considered the quality of generic drug products to be similar to brand name drug 16,25 .

What is of concern is that $46 \%$ of respondents in this study admitted to getting confused when offered more drugs with the same name or active ingredient. This proportion was highest in the public hospital, where $74 \%(n=37)$ agreed with the statement. Despite the confusion, more than half of respondents did not appear to seek advice from the pharmacists or salespersons. One respondent justified "because pharmacists never say anything right". Such distrust increases the hurdle for improving the decision competence of the patients during the purchase of drugs and other healthcare products. As suggested by Farina \& Romano-Liber 26, the role of the pharmacist should be reassessed so that pharmacies are perceived as local healthcare facilities for the population in Brazil, and not just a simple store or extended arm of the government.

The level of confidence in generic drug may depend on which manufacturer produced the generic drug. This argument appeared several times during the interviews with the three groups ("It depends a lot on the manufacturer", "I think generics are less safe depending on the manufac- turer" or "I think the smaller ones do not have quality control").

Given the importance of physicians' behavior for both patients and companions, the study also evaluated the perception of respondents concerning the preference of these professionals during the prescription process. Less than half of respondents $(36 \%)$ thought that physicians prefer to prescribe generic drug except for the hospital group, where $60 \%$ of the respondents agreed that physicians prefer to prescribe generic drug. This is aligned with the fact that public health physicians in Brazil have to prescribe drugs by their DCB or, in its absence, by the INN 8 .

Although the majority of respondents agreed that generic drug are similar in quality to brand name drug (65\%) with equal numbers of side effects $(67 \%)$ and are equally safe $(54 \%)$, the majority (74\%) agreed with the statement that "If there was no price difference, I would rather always take brand name drug", showing a preference for brand name drug if the price attribute was neutral.

Additionally, the majority $(85 \%)$ of respondents said they compare prices while shopping but only $44 \%$ of respondents said they would always buy generic drug. The patients and companions who were interviewed thought more so (48\%), while only one third of opinion-leaders (35\%) agreed and $60 \%$ disagreed. It should be noted that $83 \%$ of opinion-leaders were in the highest income category, while the other two groups of interviewees lived with much lower family incomes.

In conclusion, this study contributed to a better understanding of how Brazilian patients, their companions, and healthcare opinion-leaders value generic drugs compared to barnds name drugs. Understanding the value attributes and perceptions about generic drugs or brand name drugs may be useful in guiding new pu- 
Table 4

Perception of value attributes of generic drugs (confusion during purchase, preferences, similarity, perception of acceptance by physicians, pharmacist, salesperson, attitude during the purchase (price), equality, attitude during the purchase (preference)) by the groups surveyed.

\begin{tabular}{|c|c|c|c|c|c|c|}
\hline \multirow[t]{3}{*}{ Attribute } & & & \multirow[t]{2}{*}{ All } & \multicolumn{3}{|c|}{ Groups } \\
\hline & & & & $\begin{array}{l}\text { Patients/ } \\
\text { Companions } \\
\text { pharmacy }\end{array}$ & $\begin{array}{l}\text { Patients/ } \\
\text { Companions } \\
\text { public hospital }\end{array}$ & $\begin{array}{l}\text { Opinion- } \\
\text { leaders }\end{array}$ \\
\hline & & & n (\%) & $n(\%)$ & n (\%) & n (\%) \\
\hline \multirow{3}{*}{$\begin{array}{l}\text { Confusion } \\
\text { during } \\
\text { purchase }\end{array}$} & I get confused in the pharmacy when I & I agree & $68(46)$ & $21(42)$ & $37(74)$ & $10(21)$ \\
\hline & am offered more drugs with the same & I disagree & $79(53)$ & $28(56)$ & $13(26)$ & $38(79)$ \\
\hline & name or active ingredient & $\begin{array}{l}\text { I don't know/Did } \\
\text { not answer }\end{array}$ & $1(1)$ & $1(2)$ & $0(0)$ & $0(0)$ \\
\hline \multirow[t]{3}{*}{ Preferences } & If there was not a price difference & I agree & $109(74)$ & $36(72)$ & $38(76)$ & $35(73)$ \\
\hline & (generics are cheaper), I would always & I disagree & $36(24)$ & $12(24)$ & $12(24)$ & $12(25)$ \\
\hline & prefer taking a brand name drug & $\begin{array}{l}\text { I don't know/Did } \\
\text { not answer }\end{array}$ & $3(2)$ & $2(4)$ & $0(0)$ & $1(2)$ \\
\hline \multirow[t]{3}{*}{ Similarity } & Generic drugs are as good as brand & I agree & $96(65)$ & $28(56)$ & $35(70)$ & $33(69)$ \\
\hline & name drugs & I disagree & $36(24)$ & $13(26)$ & $12(24)$ & $11(23)$ \\
\hline & & $\begin{array}{l}\text { I don't know/Did } \\
\text { not answer }\end{array}$ & $16(11)$ & $9(18)$ & $3(6)$ & $4(8)$ \\
\hline \multirow{3}{*}{$\begin{array}{l}\text { Perception of } \\
\text { acceptance } \\
\text { by physicians }\end{array}$} & Physicians prefer to prescribe generic & I agree & $53(36)$ & $17(34)$ & $30(60)$ & $6(13)$ \\
\hline & drugs & I disagree & 87 (59) & $31(62)$ & $18(36)$ & $38(79)$ \\
\hline & & $\begin{array}{c}\text { I don't know/Did } \\
\text { not answer }\end{array}$ & $8(5)$ & $2(4)$ & $2(4)$ & $4(8)$ \\
\hline \multirow[t]{2}{*}{ Pharmacist, } & When buying medications at the & I agree & $64(43)$ & $21(42)$ & $26(52)$ & $17(35)$ \\
\hline & drugstore, I present the prescription & I disagree & $83(56)$ & $29(58)$ & $23(46)$ & $31(65)$ \\
\hline \multirow{2}{*}{ salesperson } & $\begin{array}{l}\text { and usually take advice and } \\
\text { suggestions from the pharmacist or } \\
\text { salesperson about the generic drugs }\end{array}$ & $\begin{array}{c}\text { I don't know/Did } \\
\text { not answer }\end{array}$ & $1(1)$ & $0(0)$ & $1(2)$ & $0(0)$ \\
\hline & he/she recommends & & & & & \\
\hline \multirow{3}{*}{$\begin{array}{l}\text { Attitude } \\
\text { during the } \\
\text { purchase } \\
\text { (price) }\end{array}$} & When buying medications at the & I agree & $126(85)$ & $41(82)$ & $44(88)$ & $40(85)$ \\
\hline & drugstore, I compare the prices of & I disagree & $20(14)$ & $8(16)$ & $5(10)$ & $7(15)$ \\
\hline & generic drugs and brand name drugs & $\begin{array}{c}\text { I don't know/Did } \\
\text { not answer }\end{array}$ & $2(1)$ & $1(2)$ & $1(2)$ & $1(2)$ \\
\hline \multirow[t]{3}{*}{ Equality } & I believe the generic drug is exactly & I Agree & $83(56)$ & $26(52)$ & $33(66)$ & $24(50)$ \\
\hline & the same as the brand name drug & I disagree & $55(37)$ & $16(32)$ & $16(32)$ & $23(48)$ \\
\hline & & $\begin{array}{l}\text { I don't know/Did } \\
\text { not answer }\end{array}$ & $10(7)$ & $8(16)$ & $1(2)$ & $1(2)$ \\
\hline Attitude & Even if I could afford (had money) & I agree & $65(44)$ & $24(48)$ & $24(48)$ & $17(35)$ \\
\hline during the & to buy a brand name drug, I would & I disagree & $80(54)$ & $25(50)$ & $26(52)$ & $29(60)$ \\
\hline $\begin{array}{l}\text { purchase } \\
\text { (preference) }\end{array}$ & always buy the generic drug & $\begin{array}{c}\text { I don't know/Did } \\
\text { not answer }\end{array}$ & $3(2)$ & $1(2)$ & $0(0)$ & $2(4)$ \\
\hline
\end{tabular}

blic policies and actions to ensure access to good therapeutics in Brazil. It is also important to highlight that this is only a survey of opinions, and does not necessarily reflect the actual purchase actions. Multiple factors may contribute to the decision to buy a generic drug. Price seems to be an important factor as well as effectiveness, safety, and trust. Further studies are needed to better understand the personal experiences and decision-making process regarding generic drug use and its consequences for the healthcare system and the population. 


\section{Contributors}

All authors have made intellectual contributions to the study. E. P. Nardi and M. B. Ferraz participated in its design, analysis, and interpretation of data. They also drafted the manuscript. All authors gave final approval of the version to be published.

\section{References}

1. World Health Organization. World health statistics 2013. http://www.who.int/gho/publications/ world_health_statistics/EN_WHS2013_Full.pdf (accessed on 08/Apr/2014).

2. Instituto Brasileiro de Geografia e Estatística. Pesquisa de Orçamentos Familiares 2008-2009. http:// www.ibge.gov.br/home/estatistica/populacao/con dicaodevida/pof/2008_2009/POFpublicacao.pdf (accessed on 10/Dec/2013).

3. Brasil. Presidência da República. Lei no 9.787, de 10 de fevereiro de 1999 . Altera a Lei no 6.360 , de 23 de setembro de 1976, que dispõe sobre a vigilância sanitária, estabelece o medicamento genérico, dispõe sobre a utilização de nomes genéricos em produtos farmacêuticos e dá outras providências. Diário Oficial da União 1999; 11 fev.

4. Araújo LU, Albuquerque KT, Kato KC, Silveira GS, Maciel NR, Spósito P, et al. Medicamentos genéricos no Brasil: panorama histórico e legislação. Rev Panam Salud Pública 2010; 28:480-92.
5. Rumel D, Nishioka SA, Santos AA. Intercambialidade de medicamentos: abordagem clínica e o ponto de vista do consumidor. Rev Saúde Pública 2006; 40:921-7.

6. Câmara de Regulação do Mercado de Medicamentos, Agência Nacional de Vigilância Sanitária. http://portal.anvisa.gov.br/wps/wcm/connec t/2b8303004707dcee863f9741cdd33a01/LISTA+ CONFORMIDADE_2015-01-20_v2.pdf?MOD=A JPERES (accessed on 08/Feb/2015)

7. Fundação de Proteção e Defesa do Consumidor. Relatório técnico Pesquisa Comparativa de Preços de Medicamentos, Agosto de 2013. http://www. procon.sp.gov.br/pdf/RTMedicamentos\%202013. pdf (accessed on 30/Jan/2014).

8. Agência Nacional de Vigilância Sanitária. Resolução RDC no 16, de 02 de março de 2007. Aprova o regulamento técnico para medicamentos genéricos. Diário Oficial da União 2007; 5 mar. 
9. Sindicato da Indústria de Produtos Farmacêuticos no Estado de São Paulo. Indicadores econômicos. http://sindusfarmacomunica.org.br/indicadores -economicos/ (accessed on 18/Mar/2014).

10. Quintal C, Mendes P. Underuse of generic medicines in Portugal: an empirical study on the perceptions and attitudes of patients and pharmacists. Health Policy 2012; 104:61-8.

11. Iosifescu A, Halm EA, McGinn T, Siu AL, Federman AD. Beliefs about generic drugs among elderly adults in hospital-based primary care practices. Patient Educ Couns 2008; 73:377-83.

12. Himmel W, Simmenroth-Nayda A, Niebling W, Ledig T, Jansen RD, Kochen MM, et al. What do primary care patients think about generic drugs? Int J Clin Pharmacol Ther 2005; 43:472-9.

13. Hassali MA, Shafie AA, Jamshed S, Ibrahim MI, Awaisu A. Consumers' views on generic medicines: a review of the literature. Int J Pharm Pract 2009; 17:79-88.

14. Babar ZU, Stewart J, Reddy S, Alzaher W, Vareed P, Yacoub N, et al. An evaluation of consumers' knowledge, perceptions and attitudes regarding generic medicines in Auckland. Pharm World Sci 2010; 32:440-8.

15. Shrank WH, Cox ER, Fischer MA, Mehta J, Choudhry NK. Patients' perceptions of generic medications. Health Aff (Millwood) 2009; 28: 546-56.

16. Vosgerau MZS, Souza RKT, Soares DA. Utilização de genéricos em área de atuação da equipe de saúde da família em município do sul do Brasil. Rev Bras Epidemiol 2011; 14:253-63.

17. Shrank WH, Liberman JN, Fischer MA, Girdish C, Brennan TA, Choudhry NK. Physician perceptions about generic drugs. Annals Pharmacother 2011; 45:31-8.

18. Heikkilä R, Mäntyselkä P, Hartikainen-Herranen K, Ahonen R. Customers' and physicians' opinions of and experiences with generic substitution during the first year in Finland. Health Policy 2007; 82:366-74.
19. Rodríguez-Calvillo JA, Lana A, Cueto A, Markham WA, López ML. Psychosocial factors associated with the prescription of generic drugs. Health Policy $2011 ; 101: 178-84$.

20. Sewell K, Andreae S, Luke E, Safford M. Perceptions of and Barriers to use of generic medications in a rural African American population, Alabama, 2011. Prev Chronic Dis 2012; 9:E142.

21. Agência Nacional de Vigilância Sanitária. Medicamentos de referência. http://portal.anvisa.gov. $\mathrm{br} / \mathrm{wps} / \mathrm{content/Anvisa+Portal/Anvisa/Inicio/Me}$ dicamentos/Assunto+de+Interesse/Medicamen tos+de+referencia (accessed on 31/Mar/2014).

22. Denoth A, Pinget C, Wasserfallen JB. Citizens' preferences for brand name drugs for treating acute and chronic conditions: a pilot study. Appl Health Econ Health Policy 2011; 9:81-7.

23. Håkonsen H, Eilertsen M, Borge H, Toverud EL. Generic substitution: additional challenge for adherence in hypertensive patients? Curr Med Res Opin 2009; 25:2515-21.

24. Toverud EL, Røise AK, Hogstad G, Wabø I. Norwegian patients on generic antihypertensive drugs: a qualitative study of their own experiences. Eur J Clin Pharmacol 2011; 67:33-8.

25. Bertoldi AD, Barros AJ, Hallal PC. Generic drugs in Brazil: known by many, used by few. Cad Saúde Pública 2005; 21:1808-15.

26. Farina SS, Romano-Liber NS. Pharmaceutical care in pharmacies: is there a changing process? Saude Soc 2009; 18:7-18.

27. Brasil. Presidência da República. Lei no 11.274 de 6 de fevereiro de 2006. Altera a redação dos arts. 29, 30, 32 e 87 da Lei no 9.394, de 20 de dezembro de 1996, que estabelece as diretrizes e bases da educação nacional, dispondo sobre a duração de 9 (nove) anos para o ensino fundamental, com matrícula obrigatória a partir dos 6 (seis) anos de idade. Diário Oficial da União 2006; 7 fev. 


\section{Resumo}

Avaliar as percepções de formadores de opinião, pacientes e acompanhantes em relação aos medicamentos genéricos. Foram entrevistados três grupos de participantes: (i) 50 clientes durante visitas em drogarias localizadas na cidade de São Paulo, Brasil; (ii) 25 pacientes e 25 acompanhantes durante a espera em ambulatórios clínicos; e (iii) 50 formadores de opinião do governo, hospitais, planos de saúde, academia e empresas farmacêuticas. As questões exploraram características sociodemográficas e as percepções em relação aos atributos de valores dos medicamentos genéricos comparados aos medicamentos de referência. Os respondentes tinham em média 52 anos e 53\% eram mulheres. Os participantes acreditavam que os medicamentos genéricos eram mais baratos que os medicamentos de referência (97\%) e 31\% tinham a percepção que os medicamentos genéricos são menos efetivos. Além disso, 54\% acreditavam que os medicamentos genéricos eram tão seguros quanto os medicamentos de referência e, sem uma diferença de preço, $74 \%$ preferiam os medicamentos de referências. Em conclusão, múltiplos fatores podem contribuir para a decisão de compra de um medicamentos genéricos; dentre estes, a efetividade, a segurança e o preço aparecem como os fatores mais importantes.

Medicamentos Genéricos; Medicamentos de Referência; Uso de Medicamentos

\section{Resume}

Evaluar las percepciones de los formadores de opinión, pacientes y acompañantes, en relación con las medicinas genéricas. Fueron entrevistados tres grupos: (i) 50 clientes durante visitas a farmacias ubicadas en la ciudad de São Paulo, Brasil; (ii) 25 pacientes y 25 acompañantes durante la espera en ambulatorios clínicos; y (iii) 50 formadores de opinión del gobierno, hospitales, seguros de salud, académicos y empresas farmacéuticas. Las preguntas investigaron características sociodemográficas y las percepciones en relación con los atributos de valores de las medicinas genéricas, comparados con las medicinas de referencia. Los participantes tenían en promedio 52 años y 53\% eran mujeres. Los involucrados pensaban que los medicinas genéricas eran más baratos (97\%) y 31\% tenía la percepción que las medicinas genéricas son menos efectivos. Además, $54 \%$ creía que las medicinas genéricas eran tan seguros como las medicinas de referencia y, sin diferencia de precio, $74 \%$ preferirían las medicinas de referencia. En conclusión, múltiples factores contribuyen en la decisión de compra de un medicinas genéricas; dentro de los cuales, la efectividad, la seguridad y el precio aparecen como los más importantes.

Medicamentos Genéricos; Medicamentos de

Referencia; Utilización de Medicamentos
Submitted on 12/Mar/2015

Final version resubmitted on 27/May/2015

Approved on 27/Aug/2015 